for exploration, nor means for the proper display of archæological finds for scientific study as the Federal Government has; while it is generally thought among Mexican archæologists that, had the decision gone in favour of the States, as was expected, they would not have been able to afford their monuments adequate protection from damage, illicit exploitation and other dangers.

\section{The West Indian Hurricane}

THE reports of the hurricane that devastated a large part of Cuba on November 9 after destroying most of the banana crop in Jamaica and causing serious damage and loss of life in Little Cayman and Cayman Brac, show that this was the most destructive of the four storms that have caused much loss of life in the West Indies during the hurricane season that-since it is only once in about ten years that the season extends beyond Octobershould now be ending. The latest estimates give the loss of life in Cuba alone, due mainly to the sea wave on the south coast raised presumably by the southerly hurricane immediately to the east of the storm centre, as more than two thousand. The death roll was therefore much heavier than for the hurricanes which visited the neighbourhood of Galveston on August 13 last, and the Bahamas on September 5, and even for the very violent hurricane of September 26-27 in Puerto Rico. The most recent storm was abnormal in its track as well as in the late date of its occurrence. From information given in the Times of November 11, 12, and 14, it would appear that the centre was moving northwards or a little east of north when it passed to the west of Jamaica, and towards north-east when it crossed Cuba. Many storms pass the neighbourhood of Jamaica or the seas to the south of that island, but they are nearly always moving west or north-west, and, if they recurve to north-east, do so far away and in a much higher latitude. The hurricane season of 1932 will long be remembered, although when the total number of hurricanes in this season can be determined it will probably be found that, in the past fifty years, 1886 and 1887 with eleven storms in each case, still hold first place, while 1916, with a total of eight, remains outstanding in more recent years.

\section{Optical Apparatus at the Science Museum}

A SPECIAL exhibition dealing with optical phenomena and optical instruments will be opened at the Science Museum on November 19, and will remain on view until the middle of February, 1933. A special feature of the exhibition will be a number of demonstrations and experiments operable by visitors. These will illustrate reflection, refraction, dispersion, interference, diffraction, and polarisation of light as well as the working of simple optical instruments such as the telescope and microscope. They should be of particular interest to students, especially to those who have not the facilities for performing such experiments themselves. Other demonstrations will include a large projection microscope designed for the examination of metals in large pieces, a rangefinder specially adapted to take short ranges in the Museum, a home cinematograph projector using standard size film, a large ophthalmoscope for examination of the human eye and a modern epidiascope. The historical development of various optical instruments will be illustrated by examples selected from the Museum collections, and current practice in optical instrument manufacture will be further represented by a selection of modern instruments lent by various firms especially for the exhibition.

\section{Exhibition of British Coastal Craft}

A TEMPORARY exhibition illustrating the fishing boats and coastal craft of Great Britain will be opened in the Entrance Hall of the Science Museum on November 19 and will remain on view until the middle of February, 1933. Some thirty models which have been selected mainly from the large collection of small craft exhibited in Gallery 61 of the Museum, will be shown, in addition to a collection of about sixty photographic transparencies, some of boats for which no models are available in actual use, and others of detailed plans of the more important types. The arrangement will be geographical and will thus show in their proper relations the yoles and sexerns of the Shetlands and Orkneys, the fifies and baldies of the east coast of Scotland, and the cobbles of Yorkshire, together with the eighteenth century herring-busses and the early nineteenth century three-masted luggers which fished in the North Sea. East Anglia will be represented by the distinctive sailing drifters of Yarmouth, the trawlers of Lowestoft and also by the wherries and older keels of the Broads. There will also be the many craft peculiar to the Thames estuary, the barges, lighters and bawleys, besides the older wherries and peter-boats. From the south coast there will be examples of smacks from Ramsgate and Brixham, the eighteenth century hog-boats of Brighton and the luggers which have succeeded them; also the luggers of Penzance and of Fowey. Very little has yet been written about the west coast local shipping, but several typical examples will be included.

\section{Shyok Glaciers and Indus Floods}

UNDER the above title, Mr. J. M. Lacey in an article in the Engineer for October 14 gives an account of the formation of the great ice dams which form across the Upper Shyok River in Kashmir, and of the floods in the Indus valley which result from the release of the large volumes of water pent up behind the dams. The Upper Shyok has its source in the Rima Glacier in the Karakoram region, and in its downward course passes the three important glaciers, Chong Kumdan, 9 miles long, falling 3,000 ft.; the Kichik Kumdan, 7 miles long, falling 3,500 ft. ; and the Aktash, 5 miles long, falling 2,000 ft. In the event of heavy accumulation of snow on the eastern range, these glaciers advance rapidly into the Shyok gorge. On occasions they flow right across the river until they strike the precipitous cliffs on the opposite side, and sometimes turn down the bed

No. 3290, Vol. 130] 
of the river for hundreds of yards. The first recorded damming of the Shyok occurred in 1779, the water breaking through and causing a flood the following year. Since then the river has been dammed many times but experts find great difficulty in forming any conclusion regarding the periodicity of the advance and retreat of the glaciers. One observer, Major Mason, however, considers that after 1932 there will be no danger of a block for another thirty years.

\section{Medical Uses of Radium}

The Medical Research Council has issued under the above title a summary of reports from research centres for 1931 on the radium treatment of cancer (Special Report Series, No. 174. London: H.M. Stationery Office. 1s. $3 d$. net). The main lines of radium therapy employed at present are described, and the results of the treatment of cancer of certain organs-tongue and mouth, breast, uterus, rectum, and others-are detailed. While the immediate results of the treatment are generally beneficial, the ultimate results are disappointing, few cases surviving after three or four years. But it must be remembered that most of the cases are advanced ones and inoperable. For these almost the only hope lies in radium therapy, and occasionally a striking result is obtained. Various methods of applying radium are being tested at the various centres, and we may hope in the future that improved methods will yield better results. A statistical analysis of all the cases treated at the Middlesex Hospital since 1925 is given in an appendix.

\section{New Nature Reserve in Cheshire}

AN addition of value has been made to the possessions of the Royal Society for the Protection of Birds in the Eastwood Nature Reserve, Stalybridge (Bird Notes and News, Autumn Number). The reserve, originally extending to about eight acres, was bequeathed by the Right Hon. John F. Cheetham, together with $£ 5,000$ for its upkeep. To this has been added an adjacent four acres, with $£ 500$, by a niece of the donor, Mrs. Wimbush of Taunton. The reserve is a beautiful ravine within the public park given by Mr. Cheetham to Stalybridge, and his wish that it should be kept in a natural state as regards fauna and flora will insure the continuance of a sample of wild Nature in the heart of an industrial area. Already there is abundance of wild plants and unexpected variety of birds, and judicious treatment of the reserve should add to the attractiveness of both.

\section{Announcements}

Sir Arthur Keith, who is recovering from a serious illness, has been given six months' leave of absence by the Council of the Royal College of Surgeons of England. During his absence, the duties of conservator of the Museum of the College will be taken over by Mr. R. H. Burne, physiological curator to the Museum.

$$
\text { No. 3290, Vol. 130] }
$$

The New Tank of the William Froude Laboratory at the National Physical Laboratory will be opened by the Right Hon. Stanley Baldwin on November 18 at three o'clock. Several demonstrations will be given at the opening ceremony, including screw propeller tests in the New Tank and rough water experiments in the Alfred Yarrow Tank.

A course of lectures on "The Fear of Death in Primitive Religion" will be delivered by Sir James Frazer at University College, Gower Street, London, W.C.1, on November 25, November 29 and December 1 , at 5 P.M. The lectures, although addressed to students of the University, will be open to others interested in the subject. Admission will be free and without ticket.

Prof. M. Ishimoto has been appointed director of the Earthquake Research Institute, Tokyo, in succession to Prof. K. Suyehiro, who died on April 9 of this year (see NATURE, 130, 132, 1932). Prof. Ishimoto is well known as the inventor of a tiltmeter, resembling Zöllner's horizontal pendulum, with which he has made many interesting observations on the tilts of the ground immediately preceding earthquakes.

At the anniversary meeting of the Mineralogical Society held on November 1 the following officers were elected:-President : Sir John Flett; VicePresidents : Prof. C. Gilbert Cullis, Mr. Arthur Russell ; Treasurer: Mr. F. N. Ashcroft ; General Secretary: Mr. W. Campbell Smith; Foreign Secretary: Prof. A. Hutchinson; Editor of the Journal : Dr. L. J. Spencer.

Applications are invited for the following appointments, on or before the dates mentioned:-An assistant lecturer in mathematics, mechanics and physics at the Polytechnic, Regent Street, London, W.1.-The Director of Education (Nov. 21). A joint examiner in mathematics for the Higher School Certificate Examination of the University of BristolThe Registrar (Nov. 30). Two assistant civil engin: eers for the Directorate of Works, The War Office-The Under-Secretary of State (C.5.), The War Office, London, S.W.1 (Nov. 23). A public analyst to the Metropolitan Borough of Woolwich-The Town Clerk, Town Hall, Woolwich, S.E.18 (Dec. 2). A waterfowl research assistant at the National Institute of Poultry Husbandry-The Director, National Institute of Poultry Husbandry, Newport, Salop (Dec. 5). A laboratory steward in the Department of Zoology of the University of Bristol-The Registrar (Dec. 6). A secretary, assistant librarian and assistant curator of the Manx Museum--The Curator, Manx Museum, Douglas, Isle of Man (Dec. 7). A research fellow in bacteriology at the Lister Institute of Preventive Medicine - The Secretary, Lister Institute, Chelsea Bridge Road, London, S.W.1 (Dec. 9). An independent lecturer in applied mathematics at the University College of Wales, Aberystwyth-The Secretary (Feb. 1). 